\title{
Allelopathic Activity of Dehulled Rice and its Allelochemicals on Weed Germination
}

\author{
Do Tan Khang ${ }^{1, a}$, La Hoang Anh ${ }^{1, b}$, Pham Thi Thu Ha ${ }^{1, c}$, Phung Thi Tuyen ${ }^{1, d}$, \\ Nguyen Van Quan ${ }^{1, e}$, Luong The Minh ${ }^{1, f}$, Nguyen Thanh Quan ${ }^{1,9}$, \\ Truong Ngoc Minh ${ }^{1, h}$, Tran Dang Xuan ${ }^{1, i,{ }^{*}}$, Tran Dang Khanh ${ }^{2, j}$, \\ Khuat Huu Trung, ${ }^{2, k}$
} ${ }^{1}$ Graduate School for International Development and Cooperation, Hiroshima University, Hiroshima,

\author{
${ }^{2}$ Agricultural Genetics Institute, Hanoi, Vietnam \\ adtkhang@ctu.edu.vn, bhoanganh6920@gmail.com, cphamthithuhabt@gmail.com, \\ dphungtuyen@gmail.com, enguyenquan26@gmail.com, Itminh87@gmail.com, \\ '9uanagi@gmail.com, 'minhtn689@gmail.com, 'tdxuan@hiroshima-u.ac.jp, \\ jkhanhkonkuk@gmail.com, kkhuathuutrung@yahoo.com \\ ${ }^{*}$ Corresponding author: tdxuan@hiroshima-u.ac.jp
}

Keywords: Allelochemicals, barnyardgrass, dehulled rice, phenolics, root exudates.

\begin{abstract}
In this study, the allelopathic potential of dehulled rice, rice, and hulls of rice on germination of weeds was evaluated in laboratory. Phenolic acids in growth media of these plants were also identified and quantified using HPLC. Identified allelochemicals were reversely tested for phytotoxic effects on germination and seedling growth of barnyardgrass, lettuce, radish and rice. The results showed that the inhibitory effects of dehulled rice were stronger than those of hulls and rice. Dehulled rice caused $66.7 \%$ and $50.6 \%$ reduction in radish root length and lettuce shoot height, respectively. Dehulled rice showed strong inhibitory effects on root length of lettuce and shoot height of radish while hulls and rice exhibited stimulation. Regarding phenolic identification, vanillin and vanillic acid were detected as allelochemicals in root exudates of rice and tested plants. The results revealed that most of the vanillin and vanillic acid treatments showed high inhibitory effects on germination rates and seedling growth of lettuce and radish, high stimulatory activity on root elongation of rice. Vanillic acid (100 ppm and $200 \mathrm{ppm})$, vanillin (100 ppm) and their mixture (200 ppm) completely inhibited survival of lettuce. The findings indicate the allelopathic potential of dehulled rice which can be used for identification of more phytotoxins to produce bioherbicides in agricultural practices.
\end{abstract}

\section{Introduction}

Weed is one of the most serious problems facing rice production around the world. In fact, weed invasion is responsible for more rice yield loss than pests and diseases [1]. Traditionally, handweeding is primarily applied to control weed in paddy fields; however, this approach costs a huge amount of casual labor, which has declined due to fast industrialization [2]. This phenomenon makes the conventional weed management ineffective. As a consequence, herbicides are increasingly employed as an inevitable alternative. Annually, approximately three billion tons of herbicides are used in areas of agricultural production all over the world [3]. Although herbicides are economical and effective, they cause devastating effects on the environment, human health and an increase in the risk of herbicide resistance of weeds that may threaten sustainable crop production [4-7]. To tackle the mentioned challenges in weed management for maintaining sustainable rice production, biologically novel weed treatments should be prioritized, one of which is using allelopathy as an effective and efficient manner due to its cost effective and eco-friendly aspects [7].

Among herbaceous plants possessing allelopathic property, rice has recently attracted a great deal of interest among scientists, especially after the study of Dilday et al. relating to allelopathic activity 
of rice varieties on ducksalad [Heteranthera limosa (Sw.) Wild] [8]. Allelopathic potential of rice and rice hulls has been widely studied from laboratory to greenhouse and field in many various aspects including rice germplasm, rice residues, root exudates and hull extracts [8-17]. Chung et al. [11] compared the inhibitory effect of extracts from rice straws, leaves, and hulls on barnyardgrass. Other studies also demonstrated the phytotoxicity of rice root exudates on sunflower broomrape (Orobanche cumana Wallr.) and clover broomrape (Orobanche minor Sm.) [18], barnyardgrass (Echinochloa crus-galli L.) [19], arrowhead (Sagittaria montevidensis) [20], alfalfa (Medicago sativa L.), cress (Lepidium sativum L.), lettuce (Lactuca sativa L.) [21], and hedgemustard (Sisymbrium officinale L.) [22].

However, inhibitory effects of dehulled rice (dehusked rice or brown rice) on paddy weeds are less concerned. Recently, this trend has dramatically changed that the plenty of beneficial substances in germinated brown rice has considerably captured international attention. Phenolics, one of the most abundant compounds of active phytochemicals in dehulled rice, are empirically examined to increase during germination [23]. In addition, in many previous studies, the crucial role of phenolics in allelopathy was demonstrated [10,20,24-26]. It is supposed that rice hulls play an important role in dormancy of rice or inhibition of rice germination because some inhibitory substances were found in rice hulls [27]. Biologically, mechanical removing of seed coat increases the germination speed and changes some physiological processes during germination. Thus, germination of dehulled rice may have greater allelopathic potentials comparing to intact rice seeds. Moreover, the identification and examination of rice allelochemicals and their allelopathic properties are in great demand for boosting exotic bioherbicides. Despite the fact that many studies have been conducted with rice allelochemicals, existing problems of weed control by allelopathy are still beyond the scope, and so need to be exploited in greater details. For the above reasons, this study was undertaken to evaluate allelopathic potential of dehulled rice on test plants, identify phenolic constituents from root exudates of rice and weeds, and assess phytotoxicity of phenolic acids on weed germination.

\section{Materials and methods}

\section{Plant materials}

Barnyardgrass seeds (Echinochloa crus-galli L.) were collected in paddy fields in Hiroshima, Japan in fall 2014. Lettuce (Lactuca sativa L.), and radish (Raphanus sativus L.) seeds were purchased from the Napco supermarket in Higashi-Hiroshima city, Hiroshima, Japan. Rice seeds, MNR2 cultivar (Oryza sativa L.) were provided by Cuu Long Delta Rice Research Institute, Vietnam.

\section{Effects of dehulled rice and hulls on germination of test plants}

Seeds of lettuce, radish, barnyardgrass and rice were surface-sterilized by immersion in sodium hypochlorite $0.1 \%$ for $30 \mathrm{~min}$, and then rinsed several times with distilled water. Rice seeds were dehulled to separate hulls from dehulled rice. Ten seeds of each type of weeds were placed on a sterilized Petri dish containing $10 \mathrm{~mL}$ of $0.5 \%$ agar. Simultaneously, ten seeds of rice, dehulled rice, and hulls were separately placed together with weed seeds (Fig. 1). All seeds were germinated in a growth chamber for one week during $16 \mathrm{~h}$ photoperiod at $28 / 25^{\circ} \mathrm{C}$ day/night temperature. After one week, germination rate $(\%)$, survival rate $(\%)$, shoot height $(\mathrm{cm})$ and root length $(\mathrm{cm})$ of weeds were recorded, and the inhibition or stimulation percentages of the treatments were calculated over the controls which were germinated with the absence of rice, dehulled rice or hulls. 


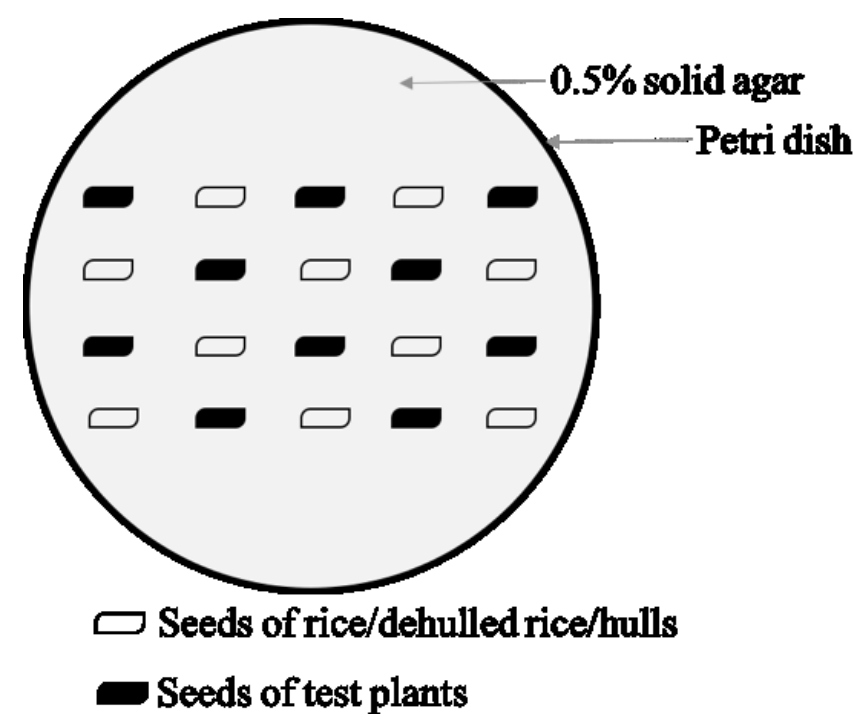

Figure 1. Diagram of seed distribution in a Petri dish

\section{Identification of phenolics released from root exudates}

Total phenolics of root exudates in agar were extracted in $99 \%$ ethanol $(20 \mathrm{~mL})$ by stirring at 500 $\mathrm{rpm}$ for $10 \mathrm{~min}$ at room temperature. The extracts were then centrifuged at $5000 \mathrm{~g}$ for $10 \mathrm{~min}$ at $20{ }^{\circ} \mathrm{C}$. The supernatants were separated and transferred to a new tube, and the residues were repeatedly extracted in $99 \%$ ethanol two more times. The combined supernatants were dried under vacuum in a rotary evaporator at $30{ }^{\circ} \mathrm{C}$. The dried extracts were dissolved in ethanol and kept at $4{ }^{\circ} \mathrm{C}$ for further analysis. Phenolic profiles of root exudates were analyzed according to the HPLC method of Xuan et al. [28]. A Jasco HPLC system (Japan) including a PU-2089 Plus pump, a LCNet/ADC controller, a UV-2075 Plus detector (set at $254 \mathrm{~nm}$ wavelength), and a J-Pak Symphonia C18 column $(5 \mu \mathrm{m} \times 4.6 \mathrm{~mm} \times 250 \mathrm{~mm})$ was employed for separation of phenolic constituents. The column temperature was $25{ }^{\circ} \mathrm{C}$. An amount of $5 \mu \mathrm{L}$ extracts was injected after being filtered through a $0.45 \mu \mathrm{m}$ filter membrane. A gradient elution of two solvents including absolute methanol (A) and $0.1 \%$ acetic acid (B) was used. The initial step began with the mobile phase A with gradient concentration from $5 \%$ to $10 \%$ in the first $5 \mathrm{~min}$, then increased from $10 \%$ to $90 \%$ for next $45 \mathrm{~min}$, and $100 \%$ for the last $10 \mathrm{~min}$. Analytical grade gallic acid, protocatechuic acid, catechol, chlorogenic acid, $p$-hydroxybenzoic acid, vanillic acid, caffeic acid, syringic acid, vanillin, ferulic acid, sinapic acid, $p$-coumaric acid, benzoic acid, ellagic acid, cinnamic acid were purchased from Sigma-Aldrich (USA) for formulation of standard curves with the concentrations ranging from 0 to $100 \mu \mathrm{g} \mathrm{mL}^{-1}$. The peaks of samples were identified and calculated based on the retention times and peak areas of phenolic standards.

\section{Effects of phenolic acids on germination of rice and test plants}

The experiment was conducted at the Physiological Laboratory, Graduate School for International Development and Cooperation, Hiroshima University, Japan. Radish, lettuce, barnyardgrass and rice were used as the test plants. Vanillin, vanillic acid and the mixture of both were applied with three concentrations of $50 \mathrm{mM}, 100 \mathrm{mM}$ and $200 \mathrm{mM}$ which were directly added in agar solution for seed germination. All seeds were surface-sterilized described previously and placed on $9 \mathrm{~cm}$ Petri dishes containing $0.5 \%$ agar with various concentrations of phenolic acids. All Petri dishes were placed in a growth chamber with $16 \mathrm{~h}$ photoperiod at $28 / 25^{\circ} \mathrm{C}$ day/night temperature. After one week, germination rate $(\%)$, survival rate $(\%)$, shoot height $(\mathrm{cm})$, and root length $(\mathrm{cm})$ of plants were recorded. The inhibition or stimulation percentages of treatments were calculated over the control (without phenolics). 


\section{Data analysis}

All treatments were performed in a completely randomized design with three replications. All data were subjected to analysis of variance (ANOVA) and the differences of means were tested with Fisher's test at $\mathrm{P}=0.05$ using the Minitab 16.0 software. Values were expressed as mean \pm standard error (SE).

\section{Results and discussion}

\section{Effects of rice, dehulled rice and hulls on germination of test plants}

Rice hulls, rice, and dehulled rice had different allelopathic potential on germination and seedling growth of barnyardgrass, lettuce, and radish (Table 1). Rice hulls, rice, and dehulled rice strongly inhibited the survival rates of radish compared to the control. The results also demonstrated that both rice and dehulled rice resulted in the decrease in lettuce shoot elongation (50.6 and 30.4\%, respectively). The results revealed inhibitory effects of dehulled rice on root length, shoot height and survival rate of barnyardgrass, lettuce, and radish. The inhibitory effect of dehulled rice was even stronger than that of hulls and rice. Particularly, dehulled rice caused $66.7 \%$ reduction in radish root length, whereas the figures were 45.7 and $41.5 \%$ in the case of hulls and rice, respectively (Table 1). Shoot height of lettuce decreased by $50.6 \%$ due to dehulled rice, but hulls and rice suppressed shoot elongation of such plant only 13.9 and $30.4 \%$, respectively (Table 1). Dehulled rice caused a significant reduction in root lengths of all three tested plants whereas hulls and rice only showed inhibitory effect on the root length of radish. Dehulled rice showed strong inhibitory effects on root length of lettuce and shoot height of radish while hulls and rice exhibited stimulatory effects.

Table 1. Effects of intact rice, dehulled rice and hulls on germination and seedling growth of weeds, expressed as different percentages over controls

\begin{tabular}{|c|c|c|c|c|}
\hline & Germination rate & Survival rate & $\begin{array}{l}\text { Shoot } \\
\text { height }\end{array}$ & $\begin{array}{l}\text { Root } \\
\text { length }\end{array}$ \\
\hline & & Barnyardgrass & & \\
\hline Barnyardgrass control & $0.0 \mathrm{ab}$ & 0.0 & 0.0 & $0.0 \mathrm{ab}$ \\
\hline Barnyardgrass + Dehulled rice & $-26.9 b c$ & 0.0 & +0.3 & $-50.7 c$ \\
\hline Barnyardgrass + Hulls & $-42.3 c$ & 0.0 & -4.2 & $+15.1 \mathrm{a}$ \\
\hline \multirow[t]{2}{*}{ Barnyardgrass + Rice } & $-42.3 \mathrm{c}$ & 0.0 & -6.3 & $-26.1 b c$ \\
\hline & & Lettuce & & \\
\hline Lettuce control & $0.0 \mathrm{a}$ & $0.0 \mathrm{ab}$ & $0.0 \mathrm{a}$ & $0.0 \mathrm{~b}$ \\
\hline Lettuce + Dehulled rice & $-20.7 \mathrm{abc}$ & $+0.4 \mathrm{ab}$ & $-50.6 \mathrm{c}$ & $-28.4 \mathrm{c}$ \\
\hline Lettuce + Hulls & $-17.2 \mathrm{ab}$ & $-3.4 a b$ & $-13.9 \mathrm{a}$ & $+37.2 \mathrm{a}$ \\
\hline \multirow{2}{*}{ Lettuce + Rice } & $-20.7 \mathrm{abc}$ & $+10.7 \mathrm{a}$ & $-30.4 b$ & $+15.8 \mathrm{~b}$ \\
\hline & & Radish & & \\
\hline Radish control & $0.0 \mathrm{a}$ & $0.0 \mathrm{a}$ & $0.0 \mathrm{~b}$ & $0.0 \mathrm{a}$ \\
\hline Radish + Dehulled rice & $-17.2 \mathrm{ab}$ & $-42.5 c$ & $-15.4 b$ & $-66.7 b$ \\
\hline Radish + Hulls & $-17.2 \mathrm{ab}$ & $-25.0 \mathrm{abc}$ & $+20.9 \mathrm{a}$ & $-45.7 b$ \\
\hline Radish + Rice & $-13.8 \mathrm{ab}$ & $-35.4 b c$ & $+20.2 \mathrm{a}$ & $-41.5 b$ \\
\hline
\end{tabular}

It is believed that dehulled rice seeds have faster speed and higher percentage of germination than intact rice seeds do [29,30]. Hulls play a pivotal role in dormancy of rice seeds [27]. Husk or seed coat may restrict the commencement of seed germination in two mechanisms, preventing the water absorption and releasing inhibitory hormones (abscisic acid) to procrastinate germination [30]. Dehulling is one of the dormancy breaking methods to activate and boost seed germination [31]. During germination, rice without covering structures may be more sensitive to the physiological 
and biochemical changes. Hence, dehulled rice could be stronger in terms of response to its surrounding environmental conditions like the existence of competitive plants such as barnyardgrass, lettuce, and radish. The findings highlighted that dehulled rice had more allelopathic activity than intact rice and hulls, opening a new scientific window for allelopathy research.

\section{Identification of allelopathic phenolics}

The results of HPLC analysis obviously revealed that there were considerable differences in compositions and concentrations of allelopathic phenolics in agar on which test plant seedlings were grown (Table 2). As can be observed in Table 2, there were ten phenolic acids including gallic, protocatechuic, chlorogenic, vanillic, syringic, ferulic, benzoic, ellagic, cinnamic acids and vanillin identified in rice and dehulled rice root exudates. Syringic and ferulic acids were only detected in dehulled rice. Furthermore, dehulled rice released more gallic and cinnamic acid than rice $(\mathrm{P}<0.05)$. Seal et al. [32] isolated and identified 25 compounds from the root exudates of both allelopathic and non-allelopathic rice varieties. Among the identified compounds, there were ten phenolic acids including salicylic, $t$-cinnamic, 2-hydroxyphenylacetic, $p$-hydroxybenzoic, 4-hydroxyphenylacetic, vanillic, syringic, $p$-coumaric, $t$-ferulic and caffeic acids. Berendji et al. [33] reported the presence of $p$-hydroxybenzoic, vanillic, $p$-coumaric, ferulic, $m$-coumaric and cinnamic acids in rice hull extracts. The chemicals released from allelopathic interference by root exudates, volatilization, or biodegradation of plant parts are called allelochemicals which play a crucial role in a sustainable weed management system [10,25].

Table 2. Phenolic acids ( $\mu \mathrm{g} \mathrm{ml}^{-1}$ extract) in agar media of weeds and rice after one-week germination

\begin{tabular}{|c|c|c|c|c|c|c|c|c|c|c|c|c|c|}
\hline & GA & $p$-HA & PA & $\mathrm{ChA}$ & VA & $\mathrm{CA}$ & SyA & $\mathrm{Vn}$ & FA & $p$-CA & BA & EA & $\mathrm{CiA}$ \\
\hline $\begin{array}{l}\text { B } \\
\text { control }\end{array}$ & $0.091 \mathrm{f}$ & $0.137 \mathrm{a}$ & $0.352 \mathrm{a}$ & $0.156 a b$ & 0.162 & $0.162 \mathrm{a}$ & & & & $0.690 \mathrm{a}$ & & $0.085 \mathrm{~d}$ & $0.097 \mathrm{c}$ \\
\hline $\begin{array}{l}\text { B + } \\
\text { DHR } \\
\text { B + H }\end{array}$ & $0.377 \mathrm{~d}$ & $\begin{array}{l}0.084 a b \\
0.030 b\end{array}$ & $\begin{array}{l}0.296 b \\
0.203 c\end{array}$ & $\begin{array}{l}0.173 a b \\
0.086 b\end{array}$ & $\begin{array}{l}0.118 \\
0.043\end{array}$ & $0.118 \mathrm{ab}$ & & $\begin{array}{l}0.331 \mathrm{~b} \\
0.274 \mathrm{~b}\end{array}$ & & $\begin{array}{l}0.468 \mathrm{ab} \\
0.284 \mathrm{ab}\end{array}$ & & $0.077 \mathrm{~d}$ & $\begin{array}{l}0.160 b c \\
0.244 b c\end{array}$ \\
\hline $\mathrm{B}+\mathrm{Ri}$ & $0.088 \mathrm{f}$ & $0.061 \mathrm{~b}$ & & & & $0.043 \mathrm{c}$ & & $1.551 \mathrm{a}$ & & $0.4948 \mathrm{ab}$ & & & $0.654 \mathrm{a}$ \\
\hline $\begin{array}{l}\mathrm{L} \\
\text { control }\end{array}$ & & & $0.031 \mathrm{~d}$ & $0.082 \mathrm{~b}$ & & & 0.171 & & & & $2.472 \mathrm{bcd}$ & & $0.083 \mathrm{c}$ \\
\hline $\begin{array}{l}\mathrm{L}+ \\
\mathrm{DHR} \\
\mathrm{L}+\mathrm{H} \\
\mathrm{L}+\mathrm{Ri}\end{array}$ & & & $\begin{array}{l}0.038 \mathrm{~d} \\
0.050 \mathrm{~d}\end{array}$ & $\begin{array}{l}0.335 \mathrm{a} \\
0.091 \mathrm{~b} \\
0.092 \mathrm{~b}\end{array}$ & $\begin{array}{l}0.149 \\
0.050\end{array}$ & & $\begin{array}{l}0.113 \\
0.140\end{array}$ & $\begin{array}{l}0.216 \mathrm{~b} \\
0.125 \mathrm{~b}\end{array}$ & & & $\begin{array}{l}1.544 \mathrm{~cd} \\
2.134 \mathrm{bcd} \\
3.698 \mathrm{ab}\end{array}$ & $\begin{array}{l}0.138 \mathrm{~d} \\
0.598 \mathrm{~b} \\
0.205 \mathrm{~cd}\end{array}$ & $\begin{array}{l}0.225 b c \\
0.330 b \\
0.143 c\end{array}$ \\
\hline $\begin{array}{l}\mathrm{Ra} \\
\text { control } \\
\mathrm{Ra}+\end{array}$ & $1.810 \mathrm{~b}$ & & & $0.316 \mathrm{a}$ & & $0.046 b c$ & 0.175 & $0.306 \mathrm{~b}$ & & & $4.153 \mathrm{ab}$ & & $0.061 \mathrm{c}$ \\
\hline $\begin{array}{l}\mathrm{DHR} \\
\mathrm{Ra}+\mathrm{H} \\
\mathrm{Ra}+\end{array}$ & $\begin{array}{l}1.105 \mathrm{c} \\
4.136 \mathrm{a}\end{array}$ & & & $0.347 \mathrm{a}$ & 0.126 & & & $\begin{array}{l}0.191 b \\
0.113 b\end{array}$ & & $0.127 \mathrm{~b}$ & $\begin{array}{l}0.873 \mathrm{~d} \\
2.341 \mathrm{bcd}\end{array}$ & $\begin{array}{l}0.112 \mathrm{~d} \\
0.394 \mathrm{bc}\end{array}$ & $\begin{array}{l}0.149 b c \\
0.543 a\end{array}$ \\
\hline $\mathrm{Ri}$ & $1.840 \mathrm{~b}$ & & & & & & 0.131 & $0.155 \mathrm{~b}$ & & & $2.937 \mathrm{abc}$ & & $0.086 \mathrm{c}$ \\
\hline $\begin{array}{l}\mathrm{Ri} \\
\text { control } \\
\text { DHR } \\
\text { control } \\
\mathrm{H} \\
\text { control }\end{array}$ & $\begin{array}{l}0.016 \mathrm{f} \\
0.242 \mathrm{e}\end{array}$ & & $0.032 \mathrm{~d}$ & $0.066 \mathrm{~b}$ & 0.039 & & 0.589 & $0.131 b$ & 0.377 & & $\begin{array}{l}4.867 \mathrm{a} \\
0.906 \mathrm{~cd}\end{array}$ & $\begin{array}{l}1.474 \mathrm{a} \\
0.323 \mathrm{~cd} \\
0.639 \mathrm{~b}\end{array}$ & $\begin{array}{l}0.164 b c \\
0.531 a \\
0.148 b c\end{array}$ \\
\hline
\end{tabular}

Means within a column, followed by the different letters are significantly different at $\mathrm{P}<0.05$.

B: Barnyardgrass; DHR: Dehulled rice; Ri: Rice; Ra: Radish; H: Hull; L: Lettuce.

GA: gallic acid; p-HA: p-hydroxybenzoic acid; PA: protocatechuic acid; ChA: chlorogenic acid; VA: vanillic acid; CA: caffeic acid; SyA: syringic acid; Vn: vanillin; FA: ferulic acid; p-CA: p-coumaric acid; BA: benzoic acid; EA: ellagic acid; CiA: cinnamic acid.

Many allelochemicals including $p$-hydroxybenzoic acid, mandelic acid, salicylic acid, vanillic acid, $p$-salicylic acid, ferulic acid, $t$-ferulic acid, $p$-coumaric acid from decomposed rice straw [34]; ferulic acid from straw extracts [11]; momilactone A and B [35]; benzoic acid, caffeic acid, $t$ coumaric acid, gentisic acid, protocatechuic acid from straw [36]; stigmastanols, 1-phenyl-2hydroxy-3,7-dimethyl-11-aldehydic-tetradecane-2-ß-D-glucopyranoside [12] were identified in rice. 
The variation of phenolic profiles in exudates of rice, dehulled rice, and hulls explained the different allelopathic effects on germination of barnyardgrass, lettuce and radish.

The phenolic profiles of root exudates from barnyardgrass, lettuce and radish were considerably changed due to the presence of dehulled rice. Vanillin was pronounced in root exudates when dehulled rice was evenly germinated with barnyardgrass although this phenolic was not found in either root exudate of dehulled rice or barnyardgrass controls. Similarly, vanillin and vanillic acid were only detected in root exudates when lettuce and dehulled rice being grown together. An amount of vanillic acid $\left(0.126 \mu \mathrm{g} \mathrm{ml}^{-1}\right.$ extract) was also found in radish exudates as rice hulls were added. There was $0.131 \mu \mathrm{g} \mathrm{ml}^{-1}$ of vanillin in root exudates of rice control, but the concentration increased ten times when rice and barnyardgrass were germinated together. The results indicated that vanillin and vanillic acid probably played the main role in alleopathic interaction of rice and weeds. Vanillin and vanillic acid were also identified as allelochemicals in different plant organs including leaves and barks of neem (Azadirachta indica) [6], leaves and stems of alfalfa (Medicago sativa L.) [28]. In a study to evaluate the allelopathic potential of rhizosphere soil of wild oat (Avena fatua L.), vanillin was identified as one of the allelochemicals which involved in the inhibitory effect against the growth of durum wheat [37]. Wu et al. [38] showed that vanillic acid detected in wheat exudates was one of the most correlated factors in inhibiting ryegrass root length. Therefore, in order to demonstrate which plants (dehulled rice or test plants) produced vanillin and vanillic acid during allelopathic interactions, pure vanillin and vanillic acid were used to examine the phytotoxic activity.

\section{Effects of selected phenolics on germination and seedling growth of weeds and rice}

Phenolic compounds are one of the most important categories of allelochemicals in the ecosystem [10,39]. The effects of vanillin, vanillic acid, and their mixture on germination and seedling growth of barnyardgrass, lettuce, radish, and rice are shown in Table 3. All phenolic treatments showed high inhibitory effects on germination rates of lettuce and radish. The greatest inhibitory activity of phenolic concentrations on germination rates of lettuce was at $200 \mathrm{ppm}$.

Table 3. Effects of allelochemicals on germination and seedling growth of test plants, expressed as different percentages over controls

\begin{tabular}{|c|c|c|c|c|c|}
\hline Treatments & Con. & GR & SR & $\mathrm{SH}$ & $\mathrm{RL}$ \\
\hline \multicolumn{6}{|c|}{ Barnyarngrass } \\
\hline \multirow[t]{2}{*}{ Control } & & $0 \mathrm{abc}$ & $0.0 \mathrm{a}$ & $0.0 \mathrm{a}$ & $0.0 \mathrm{a}$ \\
\hline & $50 \mathrm{ppm}$ & $-35.3 c$ & $0.0 \mathrm{a}$ & $-6.4 \mathrm{ab}$ & $-36.1 b$ \\
\hline \multirow[t]{2}{*}{ Vanillic acid } & 100 ppm & $+29.4 \mathrm{abc}$ & $-4.8 b$ & $+1.9 \mathrm{a}$ & $-53.9 d$ \\
\hline & 200 ppm & $-11.8 b c$ & $0.0 \mathrm{a}$ & $-17.8 b c$ & $-73.0 \mathrm{e}$ \\
\hline \multirow{3}{*}{ Vanillin } & $50 \mathrm{ppm}$ & $+23.5 \mathrm{ab}$ & $0.0 \mathrm{a}$ & $-10.9 a b$ & $+7.6 \mathrm{a}$ \\
\hline & 100 ppm & $0.0 \mathrm{abc}$ & $0.0 \mathrm{a}$ & $-11.2 a b$ & $-38.7 b c$ \\
\hline & 200 ppm & $+35.3 \mathrm{a}$ & $0.0 \mathrm{a}$ & $-17.8 b c$ & $-52.4 \mathrm{~cd}$ \\
\hline \multirow{3}{*}{ Mixture } & $50 \mathrm{ppm}$ & $+17.6 \mathrm{ab}$ & $0.0 \mathrm{a}$ & $-27.1 c$ & $-58.0 d$ \\
\hline & 100 ppm & $0.0 \mathrm{abc}$ & $0.0 \mathrm{a}$ & $-31.4 c$ & $-55.7 \mathrm{~d}$ \\
\hline & $200 \mathrm{ppm}$ & $+41.2 \mathrm{a}$ & $0.0 \mathrm{a}$ & $-30.9 c$ & $-80.6 \mathrm{e}$ \\
\hline \multicolumn{6}{|c|}{ Lettuce } \\
\hline \multirow[t]{2}{*}{ Control } & & $0.0 \mathrm{a}$ & $0.0 \mathrm{a}$ & $0.0 \mathrm{a}$ & $0.0 \mathrm{a}$ \\
\hline & $50 \mathrm{ppm}$ & $-27.6 a b$ & $-88.9 \mathrm{bcd}$ & NA & NA \\
\hline \multirow[t]{2}{*}{ Vanillic acid } & 100 ppm & $-24.1 \mathrm{ab}$ & $-100.0 \mathrm{~d}$ & NA & NA \\
\hline & 200 ppm & $-75.9 \mathrm{~cd}$ & $-100.0 \mathrm{~d}$ & NA & NA \\
\hline \multirow{5}{*}{ Vanillin } & $50 \mathrm{ppm}$ & $-37.9 b$ & $-58.3 b c$ & NA & NA \\
\hline & 100 ppm & $-51.7 b c$ & $-98.9 \mathrm{~cd}$ & NA & NA \\
\hline & 200 ppm & $-72.4 \mathrm{~cd}$ & $-66.7 \mathrm{bcd}$ & NA & NA \\
\hline & $50 \mathrm{ppm}$ & $-3.4 \mathrm{a}$ & $-56.7 b$ & $-35.7 b$ & $-97.3 b$ \\
\hline & 100 ppm & $-37.9 b$ & $-79.4 \mathrm{bcd}$ & NA & NA \\
\hline Mixture & 200 ppm & $-93.1 \mathrm{~cd}$ & $-100.0 \mathrm{~d}$ & NA & NA \\
\hline
\end{tabular}




\begin{tabular}{|c|c|c|c|c|c|}
\hline \multicolumn{6}{|c|}{ Radish } \\
\hline Control & & $0.0 \mathrm{a}$ & $0.0 \mathrm{a}$ & $0.0 \mathrm{a}$ & $0.0 \mathrm{a}$ \\
\hline \multirow{3}{*}{ Vanillic acid } & $50 \mathrm{ppm}$ & $-23.1 a b$ & $-38.4 c$ & $-36.5 b c$ & $-49.8 b$ \\
\hline & 100 ppm & $-15.4 \mathrm{a}$ & $-31.5 b c$ & $-33.0 b$ & $-63.3 b$ \\
\hline & 200 ppm & $-11.5 \mathrm{a}$ & $-47.6 \mathrm{~cd}$ & $-54.2 \mathrm{~cd}$ & $-55.8 b$ \\
\hline \multirow{3}{*}{ Vanillin } & $50 \mathrm{ppm}$ & $-3.8 \mathrm{a}$ & $-64.4 d$ & $-42.9 \mathrm{bcd}$ & $-57.2 b$ \\
\hline & 100 ppm & $-11.5 \mathrm{a}$ & $-67.1 d$ & $-53.9 \mathrm{~cd}$ & $-56.7 b$ \\
\hline & 200 ppm & $-11.5 \mathrm{a}$ & $-91.9 \mathrm{e}$ & $-42.9 \mathrm{bcd}$ & $-55.3 b$ \\
\hline \multirow{3}{*}{ Mixture } & $50 \mathrm{ppm}$ & $-23.1 \mathrm{ab}$ & $0.0 \mathrm{a}$ & $-37.9 b c$ & $-48.9 b$ \\
\hline & 100 ppm & $-50.0 b$ & $-7.7 a b$ & $-45.5 \mathrm{bcd}$ & $-50.7 b$ \\
\hline & $200 \mathrm{ppm}$ & $-46.2 b$ & $-25 b c$ & $-62.6 \mathrm{~d}$ & $-89.8 \mathrm{~b}$ \\
\hline \multicolumn{6}{|c|}{ Rice } \\
\hline \multirow[t]{2}{*}{ Control } & & $0.0 \mathrm{a}$ & 0.0 & $0.0 \mathrm{bcd}$ & $0.0 \mathrm{e}$ \\
\hline & $50 \mathrm{ppm}$ & $0.0 \mathrm{a}$ & 0.0 & $+16.4 \mathrm{a}$ & $+69.6 \mathrm{bc}$ \\
\hline \multirow[t]{2}{*}{ Vanillic acid } & 100 ppm & $0.0 \mathrm{a}$ & 0.0 & $+5.5 \mathrm{abc}$ & $+81.1 \mathrm{ab}$ \\
\hline & 200 ppm & $0.0 \mathrm{a}$ & 0.0 & $+8.5 \mathrm{ab}$ & $+40.3 \mathrm{~d}$ \\
\hline \multirow{3}{*}{ Vanillin } & $50 \mathrm{ppm}$ & $0.0 \mathrm{a}$ & 0.0 & $-0.2 \mathrm{bcd}$ & $+3.9 \mathrm{e}$ \\
\hline & 100 ppm & $0.0 \mathrm{a}$ & 0.0 & $-6.1 \mathrm{~cd}$ & $+100.4 \mathrm{a}$ \\
\hline & 200 ppm & $0.0 \mathrm{a}$ & 0.0 & $-9.6 \mathrm{de}$ & $+61.7 \mathrm{bc}$ \\
\hline \multirow[b]{3}{*}{ Mixture } & $50 \mathrm{ppm}$ & $-3.3 \mathrm{a}$ & 0.0 & $-10.0 \mathrm{de}$ & $+11.9 \mathrm{e}$ \\
\hline & 100 ppm & $-3.3 \mathrm{a}$ & 0.0 & $-9.2 \mathrm{~d}$ & $+57.5 \mathrm{~cd}$ \\
\hline & 200 ppm & $0.0 \mathrm{a}$ & 0.0 & $-21.1 \mathrm{e}$ & $+15.9 \mathrm{e}$ \\
\hline
\end{tabular}

Means, within a column, followed by the same letters are not significantly different at $\mathrm{P}<0.05$

Symbol "+" shows promotion percentage over control, and symbol "-" shows inhibition percentage over control; Con.: Concentration; NA: Not applicable (data not taken); GR: germination rate; SR: survival rate; SH: shoot height; RL: root length.

Survival rates of lettuce and radish were significantly reduced due to inhibitory effects of various concentrations of phenolic treatments. Particularly, vanillic acid (100 ppm and $200 \mathrm{ppm})$, vanillin $(100 \mathrm{ppm})$, and mixture (200 ppm) completely inhibited survival of lettuce. Moreover, vanillic acid also showed an inhibitory effect on the survival rate of barnyardgrass at $100 \mathrm{ppm}$ treatment. Biologically, vanillic acid with $1 \mathrm{mM}$ caused an increase of $47 \%$ in peroxidase activity and a decrease of $32 \%$ in phenylalnine ammonialyase activity in cucumber [40]. Shoot lengths of radish were significantly inhibited from 33.0 to $62.6 \%$ by vanillic acid, vanillin, and their mixture. Lettuce almost died before shoot height measurement, so most of the data were missed, except the treatment of $50 \mathrm{ppm}$ mixture which caused $35.7 \%$ reduction of lettuce shoot height.

The increase in treated phenolic concentrations was proportional to the significant increase in inhibition percentages. It was observed that inhibitory effects on root length of barnyardgrass and radish were dependent on the concentrations of phenolic compounds. All treatments of phenolics induced a significant reduction in root growth of barnyardgrass (except vanillin at $50 \mathrm{ppm}$ ), radish, and lettuce. The inhibition percentages ranged from 36.1 to $80.6 \%$ in barnyardgrass, from 48.9 to $89.9 \%$ in radish, and $97.3 \%$ in lettuce. The result supported by the study of Chou and Leu [41] presented that the inhibitory effects of chlorogenic, gallic, $p$-hydroxybenzoic, protocatechuic, caffeic, 3,5-dinitrozenzoic acids, and 3,4-dihydroxybenzaldehyde on lettuce increased in relation to increases in concentration from 10 to $500 \mathrm{ppm}$.

The inhibitory mechanisms of vanillin, vanillic acid, and their mixture could be explained as following reasons. Firstly, plant cell membrane permeability can be increased due to phenolic activity. This can cause a certain injury in the cell wall and then abnormal growth or even death of plant tissue [39]. Politycka [42] reported an increase in membrane permeability when cucumber was treated with benzoic acid and cinnamic acid derivatives for seven days. Secondly, phenolic compounds may cause abnormal growth and development of plant due to inhibition of cell division and elongation [37]. An illustration of this is the root length of lettuce and activity of Golgi bodies were inhibited by treated with coumarin in the study of Li et al. [39]. Moreover, benzoic acid 
inhibited more than $80 \%$ of wasabi root length with extensively damaged organelle structures of root cells [39]. Additionally, phenolic acids can affect the photosynthesis and respiration activities of plant. Patterson [43] revealed a considerable reduction of photosynthetic products and chlorophyll content of soybean (Glycine max) when $10-30 \mu \mathrm{M}$ caffeic, coumaric, ferulic, cinnamic, and vanillic acids were used. The leaf transpiration, stomatal conductance, and the intercellular $\mathrm{CO}_{2}$ concentrations of cucumber were also declined by incubating with benzoic and cinnamic acid derivatives [24].

In contrast, most of the phenolic treatments showed high stimulatory effects on root growth of rice. The highest stimulatory activity was detected in $100 \mathrm{ppm}$ of both vanillin $(100.4 \%)$ and vanillic acid $(81.1 \%)$. Vanillic acid with a low concentration $(50 \mathrm{ppm})$ showed a stimulatory effect on shoot height of rice with $16.4 \%$. Lower concentrations of phytotoxic substances may cause enhancive effects on plants [33]. From this result, it is reasonable to assume that the putative allelochemicals (vanillin and vanillic acid) were exuded from dehulled rice.

Only the mixture of vanillin and vanillic acid significantly showed a strong inhibitory effect on germination of radish compared to the individual phenolics. The mixture in all concentrations showed strong inhibitory effects on shoot height of barnyardgrass, statistically significant difference $(\mathrm{P}<0.05)$, whereas only $200 \mathrm{ppm}$ vanillic acid and vanillin could inhibit $17.8 \%$ shoot elongation of this noxious weed. Rice shoot height also significantly decreased caused by a high concentration $(200 \mathrm{ppm})$ of the phenolic mixture. In many plants, phenolic acids exist as a group, not as an individual compound. Therefore, the allelopathic activity of phenolic compounds is probably not due to a single substance [44]. Wu et al. [38] highlighted the effectiveness of phenolic combination in controlling root growth of ryegrass more significantly than individual compounds.

\section{Conclusions}

This study demonstrates that the phenolic profiles of dehulled rice and rice exudates were different, which may lead to the greater allelopathic potential of dehulled rice compared to intact rice seeds and hulls. It is suggested that vanillic acid and vanillin were allelochemicals which were exuded when barnyardgrass, lettuce or radish germinated with either rice or dehulled rice. These phenolic acids had inhibitory effects on germination and seedling growth of barnyardgrass, lettuce and radish, but stimulatory effects on rice.

\section{References}

[1] H.K. Abbas, T.K. Tanaka, S.O. Duke, et al., Susceptibility of various crop and weed species to AAL-toxin, a natural herbicide, Weed Technol. 9 (1995) 125-130.

[2] M. Olofsdotter, Allelopathy of rice, International Rice Research Institute, Bill Hardy publisher, Domenic, Los Banos, Phillipines, 1998.

[3] I.M. Chung, J. Kim, and S. Kim, Evaluation of allelopathic potential and quantification of momilactone A, B from rice hull extracts and assessment of inhibitory bioactivity on paddy field weeds, J. Agric. Food Chem. 54 (2006) 2527-2536.

[4] K. Moody, Weed management in rice, in: D. Pimenteal (ed.), Handbook of pest management in agriculture, $2^{\text {nd }}$ edition, CRC Press Boca Raton, Florida, USA. 1991, pp. 301-328.

[5] N.H. Hong, T.D. Xuan, T. Eiji, et al., Evaluation of the allelopathic potential of Kava (Piper methysticum L.) for weed control in rice, Weed Biol. Manag. 2 (2002) 143-147.

[6] T.D. Xuan, E. Tsuzuki, T. Hiroyuki, et al., Evaluation on phytotoxicity of neem (Azadirachta indica. A. Juss) to crops and weeds, Crop Prot. 23 (2004) 335-345.

[7] T.D. Khanh, L.H. Linh, T.H. Linh, et al., Integration of allelopathy to control weeds in rice. In: P. Andrew (ed.), Herbicides - current research and case studies in use, InTech, 2013.

[8] I.M. Chung, J.K. Ahn and S.J. Yun, Assessment of allelopathic potential of barnyard grass (Echinochloa crus-galli) on rice (Oryza sativa L.) cultivars, Crop Prot. 20 (2001) 921-928.

[9] J.K. Ahn, S.J. Hahn, J.T. Kim, et al., Evaluation of allelopathic potential among rice (Oryza sativa L.) germplasm for control of Echinochloa crus-galli P. Beauv in the field, Crop Prot. 24 
(2005) 413-419.

[10]I.M. Chung, K.H. Kim, J.K. Ahn, et al., Screening of allelochemicals on barnyardgrass (Echinochloa crus-galli) and identification of potentially allelopathic compounds from rice (Oryza sativa) variety hull extracts, Crop Prot. 21 (2002) 913-920.

[11]I.M. Chung, K.H. Kim, J.K. Ahn, et al., Comparison of allelopathic potential of rice leaves, straw, and hull extracts on barnyardgrass, Agron. J. 95 (2003) 1063-1070.

[12]I.M. Chung, M. Ali, A. Ahmad, et al., Chemical constituents of rice (Oryza sativa) hulls and their herbicidal activity against duckweed (Lemna paucicostata Hegelm 381), Phytochem. Anal. 17 (2006) 36-45.

[13]D.H. Dilday, P. Nastasi, and R.J. Smith, Allelopathy observation in rice (Oryza sativa L.) to ducksalad (Heteranthera limosa), Proceed. 1989 Ark. Acad. Sci. 43(1989) 11-21.

[14]D.H. Dilday, R.E. Frans, N. Semidey, et al., Weed control with crop allelopathy, Ark. Farm Res. 41 (1992)14-15.

[15]D.H. Dilday, E. Lin and W.G. Yan, Identification of allelopathy in the USDA-ARS germplasm collection, Australian J. Exp. Agric. 34 (1994) 907-910.

[16] D.H. Dilday, J.D. Mattice, K.A. Moldenhauer, et al., Allelopathic potential of rice germplasm against ducksalad, redstem and barnyardgrass, J. Crop Prod. 4 (2001) 287-301.

[17]H. Kato-Noguchi, K. Nitta, and T. Itani, Allelopathic potential of white, red and black rice cultivars, Plant Prod. Sci. 16 (2013) 305-308.

[18] Y. Ma, M. Zhang, Y. Li, et al., Allelopathy of rice (Oryza sativa L.) root exudates and its relations with Orobanche cumana Wallr. and Orobanche minor Sm. Germination, J. Plant Interact. 9 (2014) 722-730.

[19] W.S. Jung, K.H. Kim, J.K. Ahn, et al., Allelopathic potential of rice (Oryza sativa L.) residues against Echinochloa crus-galli, Crop Prot. 23 (2004) 211-218.

[20] A.N. Seal, T. Haig and J.E. Pratley, Evaluation of putative allelochemicals in rice root exudates for their role in the suppression of arrowhead root growth, J. Chem. Ecol. 30 (2004b) 16631678 .

[21] H. Kato-Noguchi, and T. Ino, Assessment of allelopathic potential of root exudate of rice seedlings, Biol. Plantarum 44 (2001) 635-638.

[22]H. Mahmoodzadeh, F. Abbasi and Y. Ghotbzadeh, Allelopathic Effects of Root Exudate and Leaching of Rice Seedlings on Hedgemustard (Sisybrium officinale), Res. J. Environ. Sci. 5 (2011) 486-492.

[23]H.H. Ti, R. Zhang, M. Zhang, et al., Dynamic changes in the free and bound phenolic compounds and antioxidant activity of brown rice at different germination stages, Food Chem. 161 (2014) 337-344.

[24]J.Q. Yu, S.F. Ye, M.F. Zhang, et al., Effects of root exudates and aqueous root extracts of cucumber (Cucumis sativus) and allelochemicals, on photosynthesis and antioxidant enzymes in cucumber, Biochem. Syst. Ecol. 31 (2003) 129-139.

[25]T.D. Khanh, T.D. Xuan and I.M. Chung, Rice allelopathy and the possibility for weed management, Ann. Appl. Biol. 151 (2007) 325-339.

[26] T.D. Xuan, I.M. Chung, T.D. Khanh, et al., Identification of phytotoxic substances from early growth of barnyard grass (Echinochloa crus-galli) root exudates, J. Chem. Ecol. 32 (2006) 895906.

[27]T. Kato, M. Tsunakawa, N. Sasaki, et al., Growth and germination inhibitors in rice husks, Phytochemistry 16 (1997) 45-48.

[28] T.D. Xuan, E. Tsuzuki, M. Matsuo, et al., Correlation between inhibitory exhibition and suspected allelochemicals in alfalfa (Medicago sativa L.), Plant Prod. Sci. 6 (2003) 165-171.

[29] A. Waheed, H. Ahmad and F.M. Abbasi, Different treatment of rice seed dormancy breaking, germination of both wild species and cultivated varieties (Oryza sativa L.), J. Mater. Environ. Sci. 3 (2012) 551-560.

[30] J. Webb, S. Miao and X-H. Zhang, Factors and mechanisms influencing seed germination in a wetland plant sawgrass, Plant Growth Regul. 57 (2009) 243-250. 
[31]E.H. Roberts, Dormancy in rice seed II: The influence of covering structures, J. Exp. Bot. 12 (1961) 430-445.

[32] A.N. Seal, J.E. Pratley, T. Haig, et al., Identification and quantitation of compounds in a series of allelopathic and non-allelopathic rice root exudates, J. Chem. Ecol. 30 (2004) 1647-1662.

[33] S. Berendji, J.B. Asghari and A.A. Matin, Allelopathic potential of rice (Oryza sativa) varieties on seedling growth of barnyardgrass (Echinochloa crus-galli), J. Plant Interact. 3 (2008) 175 180.

[34] C.H. Chou and H.J. Lin, Autointoxication mechanism of Oryza sativa. 1. Phytotoxic effects of decomposing rice residues in soils, J. Chem. Ecol. 2 (1976) 353-367.

[35] H. Kato-Noguchi, Allelopathic substance in rice root exudates: Rediscovery of momilactone B as an allelochemical, J. Plant Physiol. 161 (2004) 271-276.

[36] S. Kuwatsuka and H. Shindo, Behavior of phenolic substances in the decaying process of plants. I. Identification and quantitative determination of phenolic acids in rice straw and its decayed product by gas chromatography, Soil Sci. Plant Nutr. 19 (1973) 219-227.

[37] M. Fragasso, C. Platani, V. Miullo, et al., A bioassay to evaluate plant responses to the allelopathic potential of rhizosphere soil of wild oat (Avena fatua L.): preliminary data, Agrochimica 56 (2012) 120-128.

[38]H. Wu, T. Haig, J.E. Pratley, et al., Biochemical basis for wheat seedling allelopathy on the suppression of annual ryegrass (Lolium rigidum), J. Agric. Food Chem. 50 (2002) 4567-4571.

[39] H.H. Li, M. Inoue, H. Nishimura, et al., Interaction of trans-cinnamic acid, its related phenolic allelochemicals, and abscisic-acid in seedling growth and seed-germination of lettuce, J. Chem. Ecol. 19 (1993) 1775-1787.

[40]B. Politycka, Phenolics and the activities of phenylalanine ammonia-lysase, phenol-betaglucosyltransferase and beta-glucosidase in cucumber roots as affected by phenolic allelochemicals, Acta Physiol. Plant. 20 (1998) 405-410.

[41] C.H. Chou and L.L. Leu, Allelopathic substances and interactions of Delonix regia (BOJ) RAF, J. Chem. Ecol. 18 (1992) 2285-2303.

[42]B. Politycka, Free and glucosylated phenolics, phenol-beta-glucosyltransferase activity and membrane permeability in cucumber roots affected by derivatives of cinnamic and benzoic acid, Acta Physiol. Plant. 19 (1997) 311-317.

[43]D.T. Patterson, Effects of allelochemicals on growth and physiological response of soybean (Glycine max), Weed Sci. 29 (1981) 53-58.

[44]Z-H. Li, Q. Wang, X. Ruan, et al., Phenolics and plant allelopathy, Molecules 15 (2010) 8933 8952. 